\title{
Pengaruh Kualitas Layanan, Kualitas Produk, Promosi, dan Harga Normal terhadap Kepuasan dan Loyalitas Konsumen
}

\author{
Nathaza Gayatry Woen \\ Singgih Santoso
}

Manajemen, Universitas Kristen Duta Wacana, Indonesia

Korespondensi penulis: singgih.santoso@gmail.com

\begin{abstract}
In many marketing activities, including fast-food, customer satisfaction is an important factor for the success of a business and has the possibility to influence customer loyalty in the future. The purpose of this study is to determine the effect of service quality, product quality, promotion, and fairness of prices on customer satisfaction and customer loyalty at Burger King outlets in Yogyakarta. The research will also use gender and education level as moderation variables. By using survey methods on 377 respondents and by testing the structural model using AMOS (Analysis of Moment Structure) software version 24, the results of the study show that service quality has a significant and positive effect on customer satisfaction, product quality has a significant and positive effect on customer satisfaction, promotion does not significantly influence customer satisfaction, fairness price has a significant and positive effect on customer satisfaction, and customer satisfaction has a significant and positive effect on customer loyalty. The results also show that gender and education levels moderate the relationship between variables in the research model.
\end{abstract}

Keywords: Consumer loyalty; Normal price; Product quality; Promotion; Service quality.

Abstrak. Dalam banyak kegiatan pemasaran termasuk pada bisnis makanan cepat saji,
kepuasan pelanggan adalah faktor penting bagi keberhasilan bisnis tersebut dan memiliki
kemungkinan untuk mempengaruhi loyalitas pelanggan di masa depan. Tujuan penelitian
ini adalah untuk mengetahui pengaruh kualitas layanan, kualitas produk, promosi, dan
harga normal terhadap kepuasan konsumen dan loyalitas mereka pada produk Burger King
di Yogyakarta. Penelitian ini juga menggunakan gender dan tingkat pendidikan sebagai
variabel moderasi untuk menjelaskan hubungan antarvariabel utama tersebut. Dengan
menggunakan metode survei terhadap 377 responden dan proses pengujian model struktural
menggunakan software AMOS (Analysis of Moment Structure) versi 24 , hasil penelitian ini
menunjukkan bahwa kualitas layanan, kualitas produk, dan harga normal berpengaruh 
signifikan dan positif terhadap kepuasan konsumen, sedangkan promosi tidak berpengaruh signifikan terhadap kepuasan mereka. Selanjutnya, penelitian ini menemukan pula bahwa kepuasan konsumen berpengaruh signifikan dan positif terhadap loyalitas konsumen, serta gender dan tingkat pendidikan terbukti mampu memoderasi hubungan antarvariabel dalam model penelitian ini.

Kata kunci: Harga normal; Kualitas layanan; Kualitas produk; Loyalitas konsumen; Promosi.

Article Info:

Received: June 30, $2020 \quad$ Accepted: September 11, 2020

Available online: February 16, 2021

DOI: http://dx.doi.org/10.30588/jmp.v10i2.712

\section{LATAR BELAKANG}

Budaya manusia yang terus berkembang dan disertai pengaruh kemajuan pesat teknologi informasi dan komunikasi mengakibatkan munculnya banyak variasi dalam kegiatan konsumsi makanan. Saat ini, marak munculnya bisnis kuliner fast food (makanan cepat saji) dengan layanan pengiriman produk secara online. Makanan cepat saji dapat dibeli dan dikonsumsi dengan cepat dan mudah oleh konsumen. Konsumen tidak memerlukan waktu lama untuk mengonsumsi makanan yang dipesan, karena proses pemesanannya sangat praktis.

Pada jaman dahulu, masyarakat mengonsumsi campuran roti dan anggur sebagai makanan yang praktis untuk sarapan pagi. Jenis makanan seperti itu biasa dikonsumsi oleh orang-orang yang tidak memiliki banyak waktu atau buru-buru, karena mereka harus bekerja dan disibukkan oleh beragam kegiatan. Abad ke-20 menjadi awal mula munculnya restoran cepat saji secara formal. Restoran cepat saji yang muncul pertama kali adalah White Castle yang menyediakan hamburger dan usaha tersebut telah berdiri di Kansas, Amerika Serikat pada tahun 1916 (Anggraini, 2018). Seiring berjalannya waktu, restoran fast food semakin berkembang pesat karena dilatarbelakangi oleh pesatnya perkembangan teknologi, sehingga hal tersebut membuat pergerakan masyarakat juga menjadi lebih cepat terutama dalam hal pemenuhan kebutuhan produk-produk yang bersifat lebih praktis.

Di Indonesia, banyak bisnis fast food berkembang semakin variatif, khususnya di Daerah Istimewa Yogyakarta dengan berbagai brand, varian produk, dan harga. Kondisi tersebut memberikan gambaran bagi pelaku usaha bahwa pertumbuhan bisnis ini semakin meningkatkan intensitas persaingan bisnis. Hal ini menjadi tantangan bagi perusahaan untuk mempertahankan pelanggannya seiring dengan upaya mendapatkan keuntungan yang memadai. Bisnis fast food cepat bertumbuh di Indonesia seiring dengan peningkatan jumlah masyarakat kelas menengah (Olivia, 2020). Keberadaan masyarakat kelas menengah ini semakin menggairahkan para pelaku bisnis fast food, karena perilaku mereka yang cenderung konsumtif karena mengikuti tren gaya hidup modern (Oktavia, 2019). Perkembangan kelas menengah menjadi salah satu kunci pertumbuhan ekonomi dan kemajuan Indonesia. Bank Dunia mencatat sekitar 45\% dari populasi atau 115 juta penduduk Indonesia ber- 
potensi naik status menjadi kelas menengah di Indonesia, sehingga mereka menjadi motor perekonomian Indonesia ke depan (Olivia, 2020).

Restoran cepat saji di Indonesia hadir dengan berbagai brand. Salah satunya adalah Burger King. Sejak berdiri tahun 1953, Burger King berkembang dengan pesat tidak hanya di Amerika Serikat, tetapi ususah tersebut juga melakukan ekspansi ke banyak negara, termasuk ke Indonesia dengan puluhan cabang yang tersebar di berbagai kota besar, seperti Jakarta, Surabaya, dan Yogyakarta (Oktavia, 2019). Obyek penelitian ini adalah restoran cepat saji Burger King yang berada di wilayah Provinsi Daerah Istimewa Yogyakarta (DIY), karena daerah ini sangat prospektif menjadi lokasi usaha layanan fast food. Berdasarkan klasifikasi usaha oleh BPS (Badan Pusat Statistik) DIY, café dan restoran termasuk di dalam kategori lapangan usaha penyediaan akomodasi dan makan/minum, serta sub-kategori penyedia makan/minum.

\section{Tabel 1. Kontribusi Lapangan Usaha Penyediaan Akomodasi dan Makan/Minum terhadap PDRB DIY Tahun 2015-2019}

\begin{tabular}{ccccccc}
\hline No & Lapangan Usaha & $\mathbf{2 0 1 5}$ & $\mathbf{2 0 1 6}$ & $\mathbf{2 0 1 7}$ & $\mathbf{2 0 1 8}$ & $\mathbf{2 0 1 9}$ \\
\hline 1 & Penyedia Akomodasi & $19,7 \%$ & $20,2 \%$ & $21,1 \%$ & $22,2 \%$ & $24,4 \%$ \\
\hline 2 & Penyedia Makan/Minum & $80,3 \%$ & $79,8 \%$ & $78,9 \%$ & $77,8 \%$ & $75,6 \%$ \\
\hline & Total & $100,0 \%$ & $100,0 \%$ & $100,0 \%$ & $100,0 \%$ & $100,0 \%$ \\
\hline
\end{tabular}

Sumber: Data diolah dari BPS DIY (2019).

Pada tahun 2019, kategori penyedia akomodasi dan makan/minum berkontribusi tehadap PDRB DIY sebesar 14,63 triliun atau sekitar 75,6\% merupakan kontribusi dari sub-kategori penyediaan makan minum (restoran, café, dan sejenisnya) dan sebesar $24,4 \%$ merupakan kontribusi sub-penyedia akomodasi (hotel,losmen, dan penginapan). Secara keseluruhan, laju pertumbuhan kategori penyedia akomodasi cenderung naik, sedangkan jasa penyedia makanan dan minuman cenderung turun. Untuk tetap bertahan di tengah persaingan yang semakin ketat ini, pelaku usaha bisnis makanan/minuman harus mampu menjaga kesetiaan atau loyalitas konsumennya, sehingga konsumen akan cenderung melakukan pembelian ulang atas produk yang dipasarkannya.

Konsumen yang setia pada sebuah merek adalah mereka yang selalu melakukan pembelian berulang pada merek yang sama secara kontinyu (Kotler \& Keller, 2016). Loyalitas pelanggan telah menduduki tempat paling menonjol dalam teori dan praktik pemasaran dan berperan penting dalam implementasi usaha karena berkaitan erat dengan profitabilitas. Pemahaman mendalam tentang loyalitas konsumen produk fast food sangat diperlukan untuk memastikan keberlangsungan hidup bisnis dan dapat mengatur pertumbuhan bisnis dalam jangka panjang. Pentingnya loyalitas konsumen ini menjadi perhatian penting bagi para manajer dan banyak pelaku usaha. Persaingan bisnis yang ketat akan menimbulkan kekhawatiran para pelaku usaha agar tetap memiliki kemampuan untuk mempertahankan loyalitas konsumennya dan kualitas sebuah merek akan memiliki korelasi yang tinggi dengan kepuasan konsumen (Tjiptono, 2008). Semakin tinggi kualitas barang atau jasa yang diberikan kepada konsumen secara langsung akan meningkatkan kepuasan 
mereka. Hal tersebut dapat pula diikuti harga jual yang lebih tinggi, sehingga dalam jangka panjang keuntungan perusahaan juga akan meningkat (Tjiptono, 2008).

Dalam lingkungan yang kompetitif, berinvestasi dalam kepuasan pelanggan adalah cara menciptakan keuntungan yang berkelanjutan. Banyak hal dapat mempengaruhi kepuasan konsumen, seperti kualitas layanan, kualitas produk, harga, citra merek, dan promosi yang terbukti berpengaruh positif terhadap kepuasan konsumen dalam jangka panjang (Delima, Ashary, \& Usman, 2019). Pada penelitian lainnya, Rimawan, Mustofa, \& Mulyanto (2017) menemukan bahwa kualitas produk, kualitas layanan, dan kepercayaan tidak berpengaruh terhadap kepuasan konsumen. Perbedaan berbagai hasil penelitian sebelumnya tersebut mendasari peneliti untuk melakukan penelitian ulang, khususnya tentang variabel-variabel yang mempengaruhi pembentukan kepuasan konsumen, serta pengaruh kepuasan konsumen terhadap pembentukan loyalitas mereka. Penelitian ini juga melakukan pembaruan dengan memasukkan gender dan tingkat pendidikan sebagai variabel moderasi, karena selama ini belum ada penelitian tentang keterkaitan variabel moderasi dengan terbentuknya variabel kepuasan konsumen dan loyalitas konsumen. Dari uraian latar belakang tersebut, maka tujuan penelitian ini adalah untuk mengetahui pengaruh kualitas layanan, kualitas produk, promosi, dan kewajaran harga terhadap kepuasan konsumen dan loyalitas konsumen pada restoran cepat saji Burger King di Yogyakarta. Lebih jauh, penelitian ini juga ingin mengetahui pengaruh moderasi variabel gender dan tingkat pendidikan terhadap hubungan antarvariabel dalam model penelitian ini.

\section{KAJIAN TEORITIS}

\section{Loyalitas Konsumen}

Keuntungan dan pertumbuhan usaha menjadi stimulasi dasar yang berasal dari loyalitas konsumen. Loyalitas merupakan sebuah hasil yang secara langsung diperoleh dari kepuasan konsumen (Wu, Liao, Chen, \& Hsu, 2011). Ketika konsumen loyal, mereka dapat merasa puas dengan layanan yang diberikan atau produk yang dibeli, karena layanan atau produk tersebut sesuai harapan, sehingga mereka akan menjadi pelanggan di masa mendatang. Loyalitas atau kesetiaan konsumen dapat didefinisikan sebagai pembentukan sikap dan perilaku konsumen terhadap penggunaan produk sebagai hasil dari pengalaman konsumsi mereka sebelumnya (Griffin, 2005). Jika konsumen mendapatkan manfaat dari pembelian sebelumnya, Hal itu mengindikasikan bahwa kosumen akan melakukan repurchased (pembelian ulang). Loyalitas dapat terbentuk melalui empat tahapan, yakni loyalitas kognitif (loyalitas berdasarkan kesadaran), loyalitas afektif (loyalitas berdasarkan pengaruh), loyalitas koraktif (loyalitas berdasarkan komitmen), dan loyalitas tindakan (loyalitas dalam bentuk tindakan). Pentahapan tersebut diawali dengan sebuah motivasi yang kuat untuk mengatasi kesulitan, seperti tindakan kesetiaan (Griffin, 2005).

\section{Kepuasan Konsumen}

Pada prinsipnya, Kotler dan Keller (2016) menyatakan bahwa kepuasan konsumen adalah perasaan senang yang timbul di dalam diri seseorang setelah ia membandingkan kinerja yang dipersepsikan terhadap produk atau hasil (jasa) yang dirasakan saat mengonsumsi produk atau layanan dengan harapan mereka sebelumnya, sehingga kepuasan konsu- 
men menjadi faktor utama yang berperan penting, ketika kinerja produk atau layanan melebihi harapan konsumen. Kepuasan mencerminkan penilaian seseorang tentang ekspektasi atas kinerja produk. Jika kinerja produk gagal memenuhi harapan konsumen, maka ia akan merasa tidak puas. Namun, jika kinerja produk sesuai dengan harapan, konsumen akan merasa puas (Meesala \& Paul, 2018). Perbedaan persepsi atas keinginan dan kebutuhan pada masing-masing konsumen akan membuat perbedaan kepuasan konsumen. Saat ini, fakta menunjukkan bahwa biaya untuk menarik seorang pelanggan baru lebih mahal daripada mempertahankan seorang pelanggan dengan memuaskan mereka (Kotler \& Keller, 2016).

\section{Kualitas Layanan}

Kemampuan perusahaan dalam memberikan kualitas layanan kepada konsumen merupakan salah satu faktor keberhasilan perusahaan. Kualitas layanan jasa merupakan evaluasi kognitif konsumen saat penyerahan produk atau jasa perusahaan (Kotler \& Keller, 2016). Jika layanan yang diberikan perusahaan kepada konsumen adalah baik, maka proses tersebut akan meghasilkan kepuasan konsumen yang tinggi, serta kecenderungan terjadinya pembelian ulang yang tinggi pula (Lovelock \& Wright, 2007). Hal mendasar dalam studi Servqual (service quality) adalah lima dimensi, yakni Tangible (kemampuan perusahaan menunjukkan eksistensinya melalui faktor eksternal yang terlihat, seperti bangunan perusahaan, peralatan, dan teknologi yang digunakan), Reliability (kemampuan perusahaan memberikan layanan sesuai yang dijanjikannya), Responsiveness (kemampuan perusahaan memberikan respon cepat kepada setiap keluhan pelanggannya), Assurance (kemampuan para pegawai perusahaan untuk menumbuhkan rasa percaya kepada pelanggannya), dan Emphaty (kemampuan perusahaan memberikan perhatian tulus dan bersifat personal kepada para pelanggan), yang dapat berpengaruh pada kepuasan konsumen (Lupiyoadi \& Hamdani, 2008).

\section{Kualitas Produk}

Kualitas produk merupakan salah satu faktor penting bagi konsumen untuk menentukan pemilihan produk perusahaan. Produk yang ditawarkan perusahaan harus teruji dengan baik dan memenuhi standar minimal sesuai ketentuan. Pada dasarnya, konsumen lebih menyukai produk yang memiliki kualitas baik untuk memenuhi kebutuhan dan keinginannya. Apabila perusahaan ingin mempertahankan keunggulan kompetitifnya di pasar, perusahaan harus memahami apa yang diinginkan konsumen untuk membedakan produknya dari produk pesaing. Dimensi kualitas produk meliputi kinerja, daya tahan, kesesuaian dengan spesifikasi, fitur, reliabilitas, estetika, dan kesan akan kualitas yang diterima konsumen (Mullins, Walker, Larreche, \& Boyd, 2005).

\section{Promosi}

Dalam praktik pemasaran, kegiatan promosi seringkali menjadi faktor penentu keberhasilan kegiatan pemasaran. Tidak ada usaha berjalan tanpa kegiatan promosi. Promosi merupakan serangkaian cara yang dipakai untuk mencapai sasaran pemasaran dengan menggunakan biaya yang efektif dengan memberikan nilai tambah pada produk atau jasa, baik kepada perantara atau pun konsumen. Promosi bertujuan, antara lain menyediakan informasi, mendiferensiasi produk, menaikkan atau menstabilkan penjualan, dan menonjol- 
kan nilai produk. Sebagian besar kegiatan promosi menonjolkan nilai produk dengan menjabarkan manfaat-manfaat kepemilikan produk yang kurang dikenal pembeli (Boone \& Kurtz, 2002).

\section{Harga Normal}

Harga dipandang sebagai besar kecilnya nilai kepuasan konsumen ketika membeli sebuah produk. Seseorang akan membayar pembelian produk atau jasa dengan harga yang mahal, apabila ia memberikan nilai tinggi pada kepuasan yang diharapkannya pada produk yang dibelinya tersebut. Secara lebih luas, harga adalah jumlah dari nilai-nilai yang ditukar pelanggan atas manfaat-manfaat untuk memiliki atau menggunakan produk atau jasa tersebut (Kotler \& Keller, 2016). Harga merupakan salah satu elemen bauran pemasaran yang membutuhkan pertimbangan cermat. Hal tersebut dikarenakan adanya sejumlah dimensi stratejik harga, yaitu harga merupakan pernyataan nilai suatu produk (a statement of value), harga merupakan aspek yang tampak jelas bagi para pembeli, harga adalah determinan utama permintaan, harga berkaitan langsung dengan pendapatan dan laba perusahaan, harga adalah satu-satunya unsur bauran pemasaran yang mendapatkan pemasukan bagi perusahaan sehingga berpengaruh pada besar kecinya laba dan pangsa pasar yang diperoleh, harga bersifat fleksibel, serta harga dapat mempengaruhi citra dan strategi positioning (Tjiptono, 2008).

Harga normal dapat diukur antara lain dengan melihat apakah pelanggan merasa membayar harga yang wajar pada setiap transaksi pembeliannya, sedangkan referensi tingkat kewajaran harga mengindikasikan bahwa pelanggan merasa harga produk wajar, apabila produk atau jasa yang memiliki kesamaan jenis dari perusahaan yang berbeda tetapi ditetapkan dengan harga yang berbeda. Dengan demikian, kebijakan harga yang ditentukan oleh perusahaan dapat dinilai wajar dan diterima oleh pelanggan, sehingga kewajaran harga tersebut dianggap etis (Consuegra, Molina, \& Esteban, 2007).

\section{Hubungan Antarvariabel yang Diteliti}

\section{Pengaruh Kualitas Layanan terhadap Kepuasan Konsumen}

Layanan adalah semua kegiatan atau manfaat yang dapat ditawarkan satu pihak kepada pihak lain. Pada dasarnya, layanan tersebut mencakup kemudahan, pemeliharaan, perbaikan, dan beberapa karakteristik lainnya. Perusahaan yang mampu memenuhi kebutuhan dan keinginan konsumen akan memberikan keuntungan berupa kepuasan konsumen dan loyalitas konsumen. Beberapa penelitian mengenai kualitas layanan menunjukkan bahwa kualitas layanan berpengaruh positif terhadap kepuasan konsumen (Subaebasni, Risnawaty, \& Wicaksono, 2019). Dari uraian tersebut, hipotesis kesatu (H1) dirumuskan sebagai berikut:

\section{H1: Kualitas Layanan berpengaruh positif terhadap kepuasan konsumen.}

\section{Pengaruh Kualitas Produk terhadap Kepuasan Konsumen}

Kualitas produk adalah kemampuan suatu produk untuk melaksanakan fungsinya yang meliputi daya tahan, keandalan, ketepatan, kemudahan operasi, perbaikan, dan atri- 
but-atribut bernilai lainnya (Kotler \& Keller, 2016). Apabila perusahaan melakukan peningkatan kualitas produk, maka perusahaan tersebut dapat memuaskan konsumennya dan mampu meningkatkan jumlah konsumen. Penelitian terdahlu menunjukkan bahwa kualitas produk berpengaruh positif dan signifikan terhadap kepuasan konsumen dan loyalitas konsumen (Delima et al., 2019). Dari uraian tersebut, maka hipotesis kedua (H2) dirumuskan sebagai berikut:

\section{H2: Kualitas Produk berpengaruh positif terhadap kepuasan konsumen.}

\section{Pengaruh Promosi terhadap Kepuasan Konsumen}

Promosi adalah serangkaian teknik yang digunakan untuk mencapai sasaran penjualan atau pemasaran dengan menggunakan biaya yang efektif dengan memberikan nilai tambah pada produk atau jasa, baik kepada perantara atau pemakai (Kotler \& Keller, 2016). Promosi merupakan teknik meneruskan dan membagi informasi dari penjual kepada pembeli sebagai upaya untuk mempengaruhi sikap dan perilaku konsumen. Tanpa promosi, konsumen tidak mengenal keberadaan produk atau mereka kurang peduli mengenai keberadaan dan manfaat produk. Sejumlah riset menunjukkan bahwa promosi berpengaruh positif dan signifikan terhadap kepuasan konsumen dan loyalitas konsumen (Delima et al., 2019). Dari uraian tersebut, rumusan hipotesis ketiga (H3) dinyatakan sebagai berikut:

\section{H3: Promosi berpengaruh positif terhadap kepuasan konsumen.}

\section{Pengaruh Harga Normal terhadap Kepuasan Konsumen}

Harga normal menunjukkan kualitas suatu barang, karena barang yang berkualitas diproduksi menggunakan bahan baku yang berkualitas pula dan harganya dapat lebih mahal dari biasanya. Harga produksi yang tinggi biasanya dipersepsi oleh pelanggan sebagai produk yang berkualitas tinggi (Tjiptono, 2008). Beberapa riset menyatakan bahwa harga yang wajar atau normal berpengaruh positif dan signifikan terhadap kepuasan konsumen (Hanaysha, 2016). Dari uraian tersebut, rumusan hipotesis keempat (H4) dinyatakan sebagai berikut:

\section{H4: Harga Normal berpengaruh positif terhadap Kepuasan Konsumen.}

\section{Pengaruh Kepuasan Konsumen terhadap Loyalitas Konsumen}

Kepuasan adalah perasaan senang atau kecewa seseorang yang timbul karena membandingkan kinerja yang dipersepsikan dengan harapan konsumen. Ketika konsumen merasa puas, maka mereka cenderung akan menjadi konsumen loyal (Tjiptono, 2008). Penelitian terdahulu menunjukkan bahwa kepuasan konsumen berpengaruh positif terhadap loyalitas konsumen (Subaebasni et al., 2019). Dari hasil penelitian terdahulu dan teori yang telah dijelaskan tersebut, maka penelitian ini mengajukan hipotesis kelima (H5) sebagai berikut:

\section{H5: Kepuasan Konsumen berpengaruh positif terhadap Loyalitas Konsumen.}


Selain itu, beberapa penelitian terdahulu juga menyatakan adanya hubungan yang signifikan antara kualitas layanan, kualitas produk, dan harga yang wajar atau normal dengan kepuasan dan loyalitas konsumen (Rimawan et al., 2017). Beberapa penelitian lain juga menunjukkan hubungan antara kepuasan dan loyalitas konsumen (Dhasan \& Aryupong, 2019; Meesala \& Paul, 2018; Setiawan \& Sayuti, 2017; Subaebasni et al., 2019).

Di samping itu, penelitian ini juga menggunakan variabel moderasi gender dan tingkat pendidikan dalam model penelitian. Penggunaan variabel moderasi mempertimbangkan unsur kebaruan dalam penelitian ini dengan menempatkan tipe produk dan layanan tertentu. Sejumlah perbedaan perilaku antarkonsumen diyakini terjadi berdasarkan gender dan tingkat pendidikan. Sejumlah studi menunjukkan adanya perbedaan antara pria dan wanita terkait pengalaman mereka mengonsumsi produk, yaitu pria cenderung lebih analitis daripada wanita yang cenderung lebih subyektif (Stan, 2015). Dari uraian tersebut, rumusan hipotesis keenam (H6a dan H6b) dinyatakan sebagai berikut:

H6a: Gender memoderasi hubungan antarvariabel dalam model penelitian ini.

H6b: Tingkat Pendidikan memoderasi hubungan antarvariabel dalam model penelitian ini.

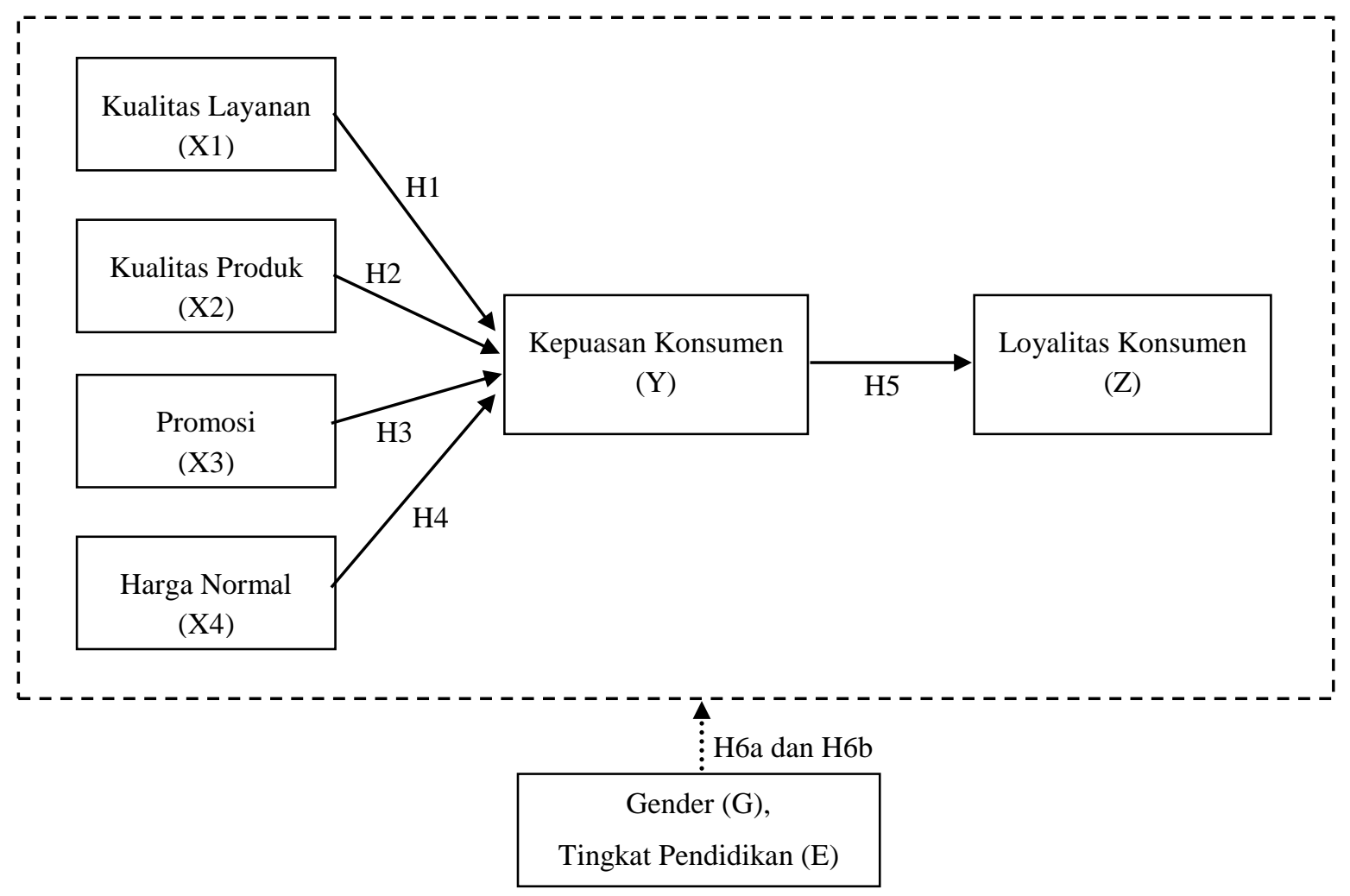

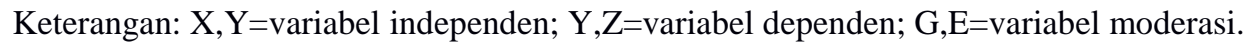

\section{Gambar 1. Model Penelitian}




\section{METODE PENELITIAN}

Penelitian ini adalah penelitian kuantitatif yang menggunakan pendekatan survei dan kuesioner untuk mengumpulkan data primer dan mengukur pendapat konsumen. Kuesioner disebarkan secara online dalam rentang waktu antara tanggal 1-14 April 2020. Obyek penelitian ini adalah konsumen Burger King di wilayah Provinsi Daerah Istimewa Yogyakarta. Pada dasarnya, kuesioner merupakan instrumen yang digunakan untuk mengumpulkan data dengan memberikan sejumlah pertanyaan kepada responden untuk mengetahui persepsi atau pendapat mereka tentang sesuatu hal. Dalam penelitian ini, kuesioner dibagi ke dalam dua bagian, yaitu: (1) profil konsumen yang menyangkut pertanyaan-pertanyaan terkait nama, jenis kelamin, usia, tingkat pendidikan, pekerjaan, dan frekuensi pembelian produk Burger King di Yogyakarta; dan (2) Pernyataan-pernyataan tentang kualitas layanan, kualitas produk, promosi, harga normal, kepuasan konsumen, dan loyalitas konsumen terhadap produk Burger King di Yogyakarta. Jawaban responden diukur menggunakan skala Likert dengan rentang jawaban 1-5 (Sangat Tidak Setuju, Tidak Setuju, Netral, Setuju, dan Sangat Setuju). Tabel 2 menunjukkan indikator untuk mengukur variabel dependen dan independen dalam penelitian ini.

\section{Tabel 2. Indikator Variabel Penelitian}

\begin{tabular}{|c|c|}
\hline Variabel & Indikator dan Referensi \\
\hline Kualitas Layanan & $\begin{array}{l}\text { (1) Kebersihan, (2) Disain outlet, (3) Kecepatan layanan, (4) Kecekatan layan- } \\
\text { an, dan (5) Kecepatan respon. } \\
\text { (Subaebasni et al., 2019) }\end{array}$ \\
\hline Kualitas Produk & $\begin{array}{l}\text { (1) Variasi menu makanan, (2) Variasi menu minuman, (3) Variasi paket menu, } \\
\text { (4) Daya tarik tampilan makanan, (5) Disain kemasan, dan (6) Rasa makanan } \\
\text { dan minuman. } \\
\text { (Subaebasni et al., 2019) }\end{array}$ \\
\hline Promosi & $\begin{array}{l}\text { (1) Kupon diskon, (2) Spanduk dan reklame outdoor, (3) Cashback, (4) } \\
\text { Promosi paket menu, dan (5) Promosi lewat media sosial. } \\
\text { (Kotler \& Keller, 2016) }\end{array}$ \\
\hline Harga Normal & $\begin{array}{l}\text { (1) Harga terjangkau, (2) Harga sesuai kualitas, (3) Harga wajar, (4) Harga } \\
\text { kompetitif. } \\
\text { (Hanaysha, 2016) }\end{array}$ \\
\hline Kepuasan Konsumen & $\begin{array}{l}\text { (1) Kepuasan terhadap harga, (2) Kepuasan terhadap layanan, (3) Kepuasan } \\
\text { terhadap promosi, dan (4) Kepuasan terhadap produk. } \\
\text { (Tjiptono, 2008) }\end{array}$ \\
\hline Loyalitas Konsumen & $\begin{array}{l}\text { (1) Rekomendasi, (2) Tujuan kuliner utama, (3) Membeli ulang, dan (4) Tidak } \\
\text { membeli burger lain. } \\
\text { (Tjiptono, 2008) }\end{array}$ \\
\hline
\end{tabular}

Sumber: Referensi terkait.

Teknik pengambilan sampel yang digunakan adalah purposive sampling, yakni sampel diambil dengan kriteria tertentu oleh peneliti. Dalam penelitian ini, pengambilan sampel dilakukan terhadap mereka yang pernah mengonsumsi produk Burger King. Sampel yang ditetapkan sebagai responden adalah konsumen yang pernah berkunjung dan membeli di 
salah satu gerai Burger King di Yogyakarta dan minimal pernah membeli menu makanan Burger King di Yogyakarta lebih dari satu kali dalam satu bulan terakhir pada saat penelitian dilakukan. Penelitian ini menggunakan metode structural equation model (SEM), sehingga jumlah sampel penelitian yang baik merujuk pada jumlah 100-400 sampel (Hair, Black, Babin, \& Anderson, 2010). Analisis data dalam penelitian ini dilakukan dengan menggunakan software AMOS (Analysis of Moment Structure) versi 24 untuk proses pengujian model struktural. Kriteria-kriteria pengujian dalam model penelitian ini tercantum pada Tabel 3.

Tabel 3. Kriteria Uji Fit Structural Equation Model (SEM)

\begin{tabular}{lc}
\hline \multicolumn{1}{c}{ Kriteria Indeks Ukuran } & Nilai Rekomendasi \\
\hline Chi-Square $\left(\chi^{2}\right)$ & Diharapkan kecil \\
\hline CMIN/df & $\leq 2,00$ \\
\hline Goodness-of-fit index (GFI) & $\geq 0,90$ \\
\hline Adjusted Goodness-of-fit Index (AGFI) & $\geq 0,80$ \\
\hline Tucker-Lewis Index (TLI) & $\geq 0,90$ \\
\hline Normed Fit Index (NFI) & $\geq 0,90$ \\
\hline Comparative Fit Index (CFI) & $\geq 0,90$ \\
Root Mean Square Error of Approximation (RMSEA) & $\leq 0,08$ \\
\hline
\end{tabular}

Sumber: Hair et al. (2010).

Tabel 4. Profil Responden

\begin{tabular}{|c|c|c|c|}
\hline & Keterangan & Jumlah & Persentase $(\%)$ \\
\hline \multirow{3}{*}{ Gender } & Laki-laki & 167 & 44,3 \\
\hline & Perempuan & 210 & 55,7 \\
\hline & Total & 377 & 100,0 \\
\hline \multirow{6}{*}{ Usia } & 18-25 tahun & 327 & 86,7 \\
\hline & 26-35 tahun & 33 & 8,8 \\
\hline & 36-45 tahun & 1 & 0,3 \\
\hline & 46-55 tahun & 10 & 2,7 \\
\hline & $>55$ tahun & 6 & 1,6 \\
\hline & Total & 377 & 100,0 \\
\hline \multirow{5}{*}{ Pendidikan } & SMA/SMK & 151 & 40,1 \\
\hline & Akademi & 16 & 4,2 \\
\hline & Sarjana & 196 & 52,0 \\
\hline & Pascasarjana & 14 & 3,7 \\
\hline & Total & 377 & 100,0 \\
\hline \multirow{6}{*}{ Pekerjaan } & Wiraswasta & 47 & 12,5 \\
\hline & Aparat sipil negara/pegawai swasta & 68 & 18,0 \\
\hline & Ibu Rumah Tangga & 9 & 2,4 \\
\hline & Mahasiswa & 184 & 48,8 \\
\hline & Lain-lain & 69 & 18,3 \\
\hline & Total & 377 & 100,0 \\
\hline \multirow{5}{*}{$\begin{array}{l}\text { Frekuensi membeli } \\
\text { dalam sebulan }\end{array}$} & Satu Kali & 89 & 23,6 \\
\hline & $2-3$ kali & 135 & 35,8 \\
\hline & $4-5 \mathrm{kali}$ & 50 & 13,3 \\
\hline & $>5$ kali & 103 & 27,3 \\
\hline & Total & 377 & 100,0 \\
\hline
\end{tabular}

Keterangan: SMA=Sekolah Menengah Atas; SMK=Sekolah Menengah Kejuruan.

Sumber: Hasil pengumpulan dan pengolahan data (2020). 


\section{HASIL DAN PEMBAHASAN}

\section{Analisis Profil Responden}

Analisis data demografi terhadap responden dapat dilihat pada Tabel 4. Berdasarkan Tabel 4 tersebut, responden perempuan lebih banyak dibandingkan dengan responden lakilaki. Dari variabel usia, sebagian besar responden berusia 18-25 tahun sebanyak 86,7\%. Responden dengan pendidikan terakhir sarjana lebih mendominasi yaitu sebanak $52 \%$. Mahasiswa adalah responden dengan jumlah terbanyak yaitu 48,8\%. Frekuensi membeli terbanyak yang dilakukan responden adalah 2-3 kali dalam sebulan terakhir, yaitu 35,8\%.

\section{Hasil Uji Kesesuaian Model (Goodness-of-Fit)}

Beberapa indeks digunakan sebagai indikator dalam evaluasi kriteria goodness-of-fit untuk menganalisis dengan menggunakan metode SEM. Tabel 5 menunjukkan hasil perhitungan kriteria goodness-of-fit pada model penelitian ini.

Tabel 5. Hasil Goodness-of-Fit Model

\begin{tabular}{lccl}
\hline Kriteria & Nilai Kritis & Indeks & Keterangan \\
\hline CMIN/DF & $\leq 5,00$ & 2,942 & Baik \\
\hline GFI & $\geq 0,90$ & 0,837 & Moderat \\
\hline AGFI & $\geq 0,80$ & 0,805 & Baik \\
\hline RMSEA & $\leq 0,08$ & 0,072 & Baik \\
\hline Sumber: Hasil pengo
\end{tabular}

Sumber: Hasil pengolahan data (2020).

Hasil uji goodness-of-fit terhadap model pada Tabel 5 tersebut menggunakan program

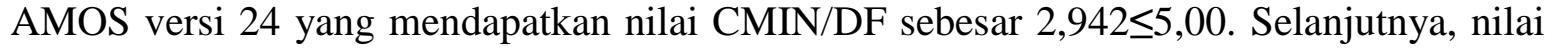
GFI sebesar $0,837 \leq 0,90$, sedangkan nilai AGFI sebesar $0,805 \geq 0,80$ dan nilai RMSEA sebesar 0,072 $\leq 0,08$. Jika ada satu atau lebih kriteria parameter telah fit, maka pengujian sebuah model dapat dinyatakan fit. Melihat hasil goodness-of-fit tersebut, maka model penelitian ini dapat diterima karena telah memenuhi sebagian besar syarat indikator kriteria goodness-of-fit.

\section{Hasil Uji Model Struktural}

Pengujian hipotesis pada model penelitian ini ditunjukkan pada Tabel 6. Hasil analisis data SEM pada model struktural menunjukkan bahwa kepuasan konsumen Burger King di Yogyakarta secara positif dan signifikan dipengaruhi oleh kualitas layanan (X1), kualitas produk (X2), dan kewajaran harga (X4). Hasil tersebut menunjukkan bahwa H1, H2, dan H4 diterima karena nilai signifikansinya menunjukkan lebih kecil daripada 0,05. Namun, kepuasan konsumen Burger King di Yogyakarta tidak dipengaruhi oleh variabel promosi (X3) atau H3 ditolak, karena nilai signifikansinya lebih besar daripada 0,05. Selanjutnya, loyalitas konsumen Burger King di Yogyakarta dipengaruhi secara positif dan signifikan oleh kepuasan konsumen atau H5 diterima, karena nilai signifikansinya lebih kecil daripada 0,05 . 
Tabel 6. Hasil Uji Model Struktural

\begin{tabular}{clcl}
\hline Hipotesis & \multicolumn{1}{c}{ Keterangan } & $\begin{array}{c}\text { Nilai } \\
\text { Signifikansi }\end{array}$ & \multicolumn{1}{c}{ Pengaruh } \\
\hline $\mathrm{H}_{1}$ & Kualitas Layanan $\rightarrow$ Kepuasan Konsumen & 0,000 & Signifikan \\
\hline $\mathrm{H}_{2}$ & Kualitas Produk $\rightarrow$ Kepuasan Konsumen & 0,000 & Signifikan \\
\hline $\mathrm{H}_{3}$ & Promosi $\rightarrow$ Kepuasan Konsumen & 0,508 & Tidak Signifikan \\
\hline $\mathrm{H}_{4}$ & Kewajaran Harga $\rightarrow$ Kepuasan Konsumen & 0,000 & Signifikan \\
\hline $\mathrm{H}_{5}$ & Kepuasan Konsumen $\rightarrow$ Loyalitas Konsumen & 0,000 & Signifikan \\
\hline
\end{tabular}

Sumber: Hasil pengolahan data (2020).

\section{Hasil Analisis Uji Moderasi Gender Laki-laki dan Perempuan}

Hasil pengujian untuk variabel gender menunjukkan bahwa kepuasan konsumen pada responden laki-laki di Yogyakarta dipengaruhi oleh kualitas produk dan kewajaran harga (Tabel 7). Namun, kualitas layanan dan promosi tidak berpengaruh pada kepuasan konsumen laki-laki, sedangkan kepuasan tersebut memberikan dampak positif dan signifikan pada loyalitas mereka untuk membeli produk Burger King secara berulang.

Pada responden perempuan di Yogyakarta, kepuasan konsumen dipengaruhi oleh kualitas layanan, promosi, dan kewajaran harga. Namun, kualitas produk tidak berpengaruh pada kepuasan mereka, sedangkan kepuasan responden perempuan berdampak pada loyalitas mereka terhadap produk Burger King (Tabel 8). Hasil penelitian ini menunjukkan bahwa responden laki-laki di Yogyakarta tidak mudah tertarik dengan diskon yang diberikan oleh perusahaan dan mereka lebih memperhatikan untuk mendapatkan solusi atas rasa lapar dan puas jika mereka merasa kenyang, sehingga mereka kurang memperhatikan layanan yang diberikan.

Tabel 7. Hasil Uji Hipotesis pada Gender Laki-laki

\begin{tabular}{clcl}
\hline Hipotesis & \multicolumn{1}{c}{ Keterangan } & $\begin{array}{c}\text { Nilai } \\
\text { Signifikansi }\end{array}$ & \multicolumn{1}{c}{ Pengaruh } \\
\hline $\mathrm{H}_{1 \mathrm{GL}}$ & Kualitas Layanan $\rightarrow$ Kepuasan Konsumen & 0,305 & Tidak Signifikan \\
$\mathrm{H}_{2 \mathrm{GL}}$ & Kualitas Produk $\rightarrow$ Kepuasan Konsumen & 0,000 & Signifikan \\
$\mathrm{H}_{3 \mathrm{GL}}$ & Promosi $\rightarrow$ Kepuasan Konsumen & 0,991 & Tidak Signifikan \\
$\mathrm{H}_{4 \mathrm{GL}}$ & Kewajaran Harga $\rightarrow$ Kepuasan Konsumen & 0,000 & Signifikan \\
$\mathrm{H}_{5 \mathrm{GL}}$ & Kepuasan Konsumen $\rightarrow$ Loyalitas Konsumen & 0,000 & Signifikan \\
\hline
\end{tabular}

Keterangan: Hipotesis dengan moderasi GL (Gender Laki-laki).

Sumber: Hasil pengolahan data (2020).

Hal tersebut juga menunjukkan bahwa kualitas produk berpengaruh terhadap kepuasan konsumen laki-laki di Yogyakarta. Apabila produk yang mereka beli diraskan enak saat dikonsumsi dan harga yang ditawarkan sesuai ekspektasi mereka, maka hal itu dapat memberikan rasa puas pada konsumen laki-laki dan membuat mereka menjadi loyal. Di sisi lain, responden perempuan di Yogyakarta lebih mudah dipengaruhi dengan penawaran diskon dan mereka lebih cepat tertarik dengan program sale, sehingga mereka pun kurang memperhatikan kualitas produk. Hasil ini sejalan dengan temuan tentang layanan di rumah 
sakit (Meesala \& Paul, 2018) dan kepuasan pelanggan di hotel (Mohsan, Nawaz, Khan, Shaukat, \& Aslam, 2011).

Tabel 8. Hasil Uji Hipotesis pada Gender Perempuan

\begin{tabular}{clcl}
\hline Hipotesis & \multicolumn{1}{c}{ Keterangan } & $\begin{array}{c}\text { Nilai } \\
\text { Signifikansi }\end{array}$ & \multicolumn{1}{c}{ Pengaruh } \\
\hline $\mathrm{H}_{1 \mathrm{GP}}$ & Kualitas Layanan $\rightarrow$ Kepuasan Konsumen & 0,000 & Signifikan \\
$\mathrm{H}_{2 \mathrm{GP}}$ & Kualitas Produk $\rightarrow$ Kepuasan Konsumen & 0,624 & Tidak Signifikan \\
$\mathrm{H}_{3 \mathrm{GP}}$ & Promosi $\rightarrow$ Kepuasan Konsumen & 0,020 & Signifikan \\
$\mathrm{H}_{4 \mathrm{GP}}$ & Kewajaran Harga $\rightarrow$ Kepuasan Konsumen & 0,000 & Signifikan \\
$\mathrm{H}_{5 \mathrm{GP}}$ & Kepuasan Konsumen $\rightarrow$ Loyalitas Konsumen & 0,000 & Signifikan \\
\hline
\end{tabular}

Keterangan: Hipotesis dengan moderasi GP (Gender Perempuan).

Sumber: Hasil pengolahan data (2020).

\section{Analisis Uji Moderasi Tingkat Pendidikan SMA/SMK dan Sarjana}

Berikut ini diuraikan hasil pengujian moderasi berdasarkan tingkat pendidikan responden. Dalam penelitian ini, variabel moderasi tingkat pendidikan difokuskan pada dua kategori tingkat pendidikan yang mendominasi latar belakang pendidikan responden, yaitu SMA/SMK dan sarjana. Hasil pengujian moderasi berdasarkan variabel tingkat pendidikan responden menunjukkan bahwa kepuasan responden yang berpendidikan SMA/SMK dipengaruhi oleh kualitas layanan dan kewajaran harga (Tabel 9). Namun, kualitas produk dan promosi tidak terbukti berpengaruh signifikan terhadap kepuasan mereka, sedangkan kepuasan responden berpendidikan SMA/SMK di Yogyakarta berdampak signifikan terhadap loyalitas mereka terhadap produk Burger King.

Tabel 9. Hasil Uji Hipotesis Berdasarkan Pendidikan Tingkat SMA/SMK

\begin{tabular}{clcl}
\hline Hipotesis & \multicolumn{1}{c}{ Keterangan } & $\begin{array}{c}\text { Nilai } \\
\text { Signifikansi }\end{array}$ & \multicolumn{1}{c}{ Pengaruh } \\
\hline $\mathrm{H}_{1 \mathrm{EM}}$ & Kualitas Layanan $\rightarrow$ Kepuasan Konsumen & 0,003 & Signifikan \\
$\mathrm{H}_{2 \mathrm{EM}}$ & Kualitas Produk $\rightarrow$ Kepuasan Konsumen & 0,089 & Tidak Signifikan \\
$\mathrm{H}_{3 \mathrm{EM}}$ & Promosi $\rightarrow$ Kepuasan Konsumen & 0,181 & Tidak Signifikan \\
$\mathrm{H}_{4 \mathrm{EM}}$ & Kewajaran Harga $\rightarrow$ Kepuasan Konsumen & 0,000 & Signifikan \\
$\mathrm{H}_{5 \mathrm{EM}}$ & Kepuasan Konsumen $\rightarrow$ Loyalitas Konsumen & 0,000 & Signifikan \\
\hline
\end{tabular}

Keterangan: Hipotesis dengan moderasi EM (Edukasi tingkat Menengah yaitu SMA/SMK).

Sumber: Hasil pengolahan data (2020).

Pada pengujian moderasi berdasarkan tingkat pendidikan sarjana, kepuasan konsumen dipengaruhi oleh kualitas produk, kualitas layanan, dan kewajaran harga (Tabel 10). Pada pengujian tersebut, hanya variabel promosi yang tidak menunjukkan pengaruh terhadap kepuasan mereka, sedangkan kepuasan responden yang berpendidikan sarjana memberikan dampak pengaruh yang signifikan terhadap loyalitas mereka pada Burger King di Yogyakarta. Bagi konsumen berpendidikan sarjana, kualitas layanan, kualitas produk, dan kewajaran harga dapat meningkatkan kepuasan maupun loyalitas mereka. Dalam 
penelitian ini, tingkat pendidikan terbukti mampu menjadi moderator pada hubungan antarvariabel dalam model penelitian ini.

Tabel 10. Hasil Uji Hipotesis Berdasarkan Pendidikan Tingkat Sarjana

\begin{tabular}{clcl}
\hline Hipotesis & \multicolumn{1}{c}{ Keterangan } & $\begin{array}{c}\text { Nilai } \\
\text { Signifikansi }\end{array}$ & \multicolumn{1}{c}{ Pengaruh } \\
\hline $\mathrm{H}_{1 \mathrm{ES}}$ & Kualitas Layanan $\rightarrow$ Kepuasan Konsumen & 0,006 & Signifikan \\
$\mathrm{H}_{2 \mathrm{ES}}$ & Kualitas Produk $\rightarrow$ Kepuasan Konsumen & 0,032 & Signifikan \\
$\mathrm{H}_{3 \mathrm{ES}}$ & Promosi $\rightarrow$ Kepuasan Konsumen & 0,510 & Tidak Signifikan \\
$\mathrm{H}_{4 \mathrm{ES}}$ & Kewajaran Harga $\rightarrow$ Kepuasan Konsumen & 0,000 & Signifikan \\
$\mathrm{H}_{5 \mathrm{ES}}$ & Kepuasan Konsumen $\rightarrow$ Loyalitas Konsumen & 0,000 & Signifikan \\
\hline
\end{tabular}

Keterangan: Hipotesis dengan moderasi ES (Edukasi tingkat Sarjana).

Sumber: Hasil pengolahan data (2020).

Bagi responden yang berpendidikan SMA/SMK maupun sarjana, kualitas layanan dan kewajaran harga terbukti menjadi variabel yang berpengaruh signifikan terhadap kepuasan mereka terhadap produk Burger King di Yogyakarta. Artinya, semakin baik kualitas layanan atau semakin wajar harga yang ditawarkan pada penjualan produk Burger King di Yogyakarta, maka konsumen cenderung semakin puas dan memberikan kontribusi pada terbentuknya loyalitas mereka terhadap produk tersebut. Di sisi lain, responden dengan tingkat pendidikan SMA/SMK dan sarjana menanggapi berbeda atas pengaruh variabel kualitas produk terhadap kepuasan mereka. Hal ini dapat disebabkan oleh pola pemikiran responden berpendidikan sarjana lebih dewasa daripada mereka yang berpendidikan SMA/ SMK, sehingga mereka cenderung lebih memperhatikan kualitas produk ketika membeli produk Burger King. Secara ringkas, Tabel 11 menunjukkan rekapitulasi hasil uji hipotesis dalam model penelitian ini.

Tabel 11. Rekapitulasi Hasil Uji Hipotesis

\begin{tabular}{clccccc}
\hline Hipotesis & \multicolumn{1}{c}{ Keterangan } & Model & GL & GP & EM & ES \\
\hline $\mathrm{H}_{1}$ & Kualitas Layanan $\rightarrow$ Kepuasan Konsumen & $\mathrm{S}$ & $\mathrm{TS}$ & $\mathrm{S}$ & $\mathrm{S}$ & $\mathrm{S}$ \\
$\mathrm{H}_{2}$ & Kualitas Produk $\rightarrow$ Kepuasan Konsumen & $\mathrm{S}$ & $\mathrm{S}$ & $\mathrm{TS}$ & $\mathrm{TS}$ & $\mathrm{S}$ \\
$\mathrm{H}_{3}$ & Promosi $\rightarrow$ Kepuasan Konsumen & $\mathrm{TS}$ & $\mathrm{TS}$ & $\mathrm{S}$ & $\mathrm{TS}$ & $\mathrm{TS}$ \\
$\mathrm{H}_{4}$ & Kewajaran Harga $\rightarrow$ Kepuasan Konsumen & $\mathrm{S}$ & $\mathrm{S}$ & $\mathrm{S}$ & $\mathrm{S}$ & $\mathrm{S}$ \\
$\mathrm{H}_{5}$ & Kepuasan Konsumen $\rightarrow$ Loyalitas Konsumen & $\mathrm{S}$ & $\mathrm{S}$ & $\mathrm{S}$ & $\mathrm{S}$ & $\mathrm{S}$ \\
\hline
\end{tabular}

Keterangan:

S=Signifikan; TS=Tidak Signifikan.

GL=Gender Laki-laki; GP=Gender Perempuan.

EM=Edukasi Menengah (SMA/SMK); ES=Edukasi Sarjana.

\section{Pembahasan}

Hasil analisis data menunjukkan bahwa semakin tinggi kualitas layanan yang diberikan oleh restoran cepat saji Burger King di Yogyakarta cenderung mampu meningkatkan kepuasan pelanggannya. Ketika layanan dirasakan oleh konsumen sesuai dengan harapan- 
nya, maka mereka merasa lebih diperhatikan. Jika layanan yang diberikan dirasa sangat membantu ketika konsumen mengalami kesulitan, hal itu dapat mempermudah aktivitas konsumen. Hasil penelitian ini sama dengan penelitian yang dilakukan oleh sejumlah peneliti tentang dampak kepuasan konsumen yang dapat mendorong peningkatan loyalitas konsumen (Abdullah, Hamir, Nor, Krishnaswamy, \& Rostum, 2018; Joudeh \& Dandis, 2018; Karyose, Astuti, \& Ferdiansjah, 2017).

Penelitian ini juga menunjukkan bahwa kualitas produk berpengaruh secara signifikan dan positif terhadap kepuasan pelanggan Burger King di Yogyakarta. Hasil ini menunjukkan dan menerangkan bahwa semakin tinggi kualitas produk restoran cepat saji Burger King di Yogyakarta, kepuasan yang dirasakan oleh konsumen atas produk tersebut akan meningkat pula. Produk yang ditawarkan berkualitas merupakan first impression yang baik bagi konsumen. Jika produk yang ditawarkan membuat konsumen terkesan, maka mereka cenderung akan melakukan pembelian produk tersebut kembali. Produk makanan burger yang dianggap lezat dan bervariasi dapat menentukan selera dan pilihan konsumen agar mereka merasa puas mengonsumsinya. Ketika konsumen merasa puas, maka kepuasan konsumen tersebut akan menimbulkan kesan positif terhadap Burger King di Yogyakarta, sehingga jumlah konsumen akan cenderung meningkat. Hasil penelitian ini selaras dengan beberapa penelitian sebelumnya (Dhasan \& Aryupong, 2019; Jahanshahi, Gashti, Mirdamadi, Nawaser, \& Khaksar, 2011; Khoironi, Syah, \& Dongoran, 2018).

Tidak berpengaruhnya variabel promosi terhadap kepuasan konsumen dapat diindikasikan bahwa promosi yang dilakukan oleh Burger King di Yogyakarta hanya dapat dirasakan oleh sebagian konsumen saja. Misalnya, program promosi cashback dengan metode pembayaran yang ditawarkan oleh Burger King di Yogyakarta hanya dapat dinikmati oleh orang-orang tertentu yang memiliki aplikasi OVO, Gopay, dan Dana. Responden yang mengisi kuesioner pada penelitian ini kemungkinan adalah mereka yang tidak terlalu merasakan dampak promosi yang diberikan tersebut. Selain itu, Burger King merupakan restoran cepat saji yang brandnya cukup dikenal, sehingga banyak di antara mereka yang tidak asing lagi mendengar merek Burger King. Hasil penelitian ini bertolak belakang dengan beberapa penelitian tentang pengaruh promosi terhadap penjualan (Delima et al., 2019; Ishaq, Bhutta, Hamayun, Danish, \& Hussain, 2014; Rimawan et al., 2017).

Tingkat harga normal yang berpengaruh terhadap kepuasan konsumen Burger King di Yogyakarta menunjukkan bahwa semakin wajar harga yang ditetapkan pada produk akan meningkatkan kepuasan pelanggan atas kewajaran harga tersebut. Sebagian konsumen sangat sensitif terhadap harga produk. Jika harga yang ditawarkan tidak wajar dengan ekspektasi konsumen dapat mengakibatkan konsumen merasa tidak puas. Sebaliknya, semakin wajar harga produk dengan kualitas tertentu, maka konsumen cenderung akan merasa puas. Ketika harga produk relatif murah dan produk makanan yang ditawarkan dirasakan lezat bagi konsumen, maka mereka akan merasa sangat puas dan memungkinkan untuk mengulangi pembelian lagi di kemudian hari. Hasil penelitian ini sama dengan yang ditunjukkan oleh sejumlah penelitian terdahulu tentang hal tersebut (Abdullah et al., 2018; Marina, Kartini, Sari, \& Padmasasmita, 2016; Yaqub, Halim, \& Shehzad, 2019).

Kepuasan konsumen yang berpengaruh positif dan signifikan terhadap loyalitas pelanggan atas produk Burger King di Yogyakarta menunjukkan bahwa semakin tinggi 
kepuasan konsumen akan membuat pelanggannya menjadi setia dan cenderung melakukan pembelian ulang. Namun, jika tingkat kepuasan konsumen Burger King semakin rendah, maka tingkat loyalitas konsumennya pun semakin rendah dan cenderung tidak akan melakukan pembelian ulang. Hasil penelitian ini sejalan dengan beberapa penelitian sebelumnya (Jahanshahi et al., 2011; Khoironi et al., 2018; Rimawan et al., 2017).

\section{KESIMPULAN DAN SARAN}

Hasil analisis data menunjukkan secara sosio demografi, mayoritas responden dalam penelitian ini adalah wanita, berusia 18-25 tahun, berpendidikan Sarjana, berprofesi sebagai mahasiswa, dan rata-rata telah berkunjung dan membeli produk Burger King di Yogyakarta sebanyak 2-3 kali dalam satu bulan terakhir. Hasil pengujian model penelitian ini menunjukkan bahwa variabel kualitas produk, kualitas layanan, dan harga normal berpengaruh secara signifikan dan positif terhadap kepuasan konsumen Burger King di Yogyakarta, sedangkan variabel promosi tidak berpengaruh signifikan terhadap kepuasan mereka. Selanjutnya, konsumen yang merasa puas berdampak terhadap meningkatnya loyalitas mereka. Penelitian ini juga menunjukkan bahwa gender dan tingkat pendidikan konsumen mampu memoderasi pengaruh variabel independen terhadap variabel dependen dalam model penelitian ini.

Berdasarkan kesimpulan tersebut, Burger King di Yogyakarta sebaiknya lebih memperhatikan aspek kualitas layanan, kualitas produk, promosi, dan harga normal dalam upaya menambah jumlah pelanggan atau pun membangun loyalitas mereka. Selain itu, hasil penelitian ini juga dapat digunakan sebagai masukan bagi para praktisi untuk memperhatikan faktor sosio demografi, misalnya cara dan teknik mempengaruhi konsumen perempuan, mempraktikan promosi yang menarik dengan menonjolkan variasi produk, variasi rasa tambahan, dan lain-lain. Penelitian selanjutnya dapat memasukkan variabel moderasi lain, seperti usia, pekerjaan, maupun tingkat pengeluaran per bulan untuk mempertajam hasil analisis.

\section{DAFTAR REFERENSI}

Abdullah, D., Hamir, N., Nor, N. M., Krishnaswamy, J., \& Rostum, A. M. M. (2018). Food Quality, Service Quality, Price Fairness and Restaurant Re-patronage Intention: The Mediating Role of Customer Satisfaction. International Journal of Academic Research in Business and Social Sciences, 8(17), 211-226.

Anggraini, A. P. (2018). Begini Awal Mula Makanan Cepat Saji Muncul... Diakses di: https://lifestyle.kompas.com/read/2018/03/16/141907920/begini-awal-mulamakanan-cepat-saji-muncul?page $=$ all.

Boone, L. E., \& Kurtz., D. L. (2002). Pengantar Bisnis. Jilid 2. Jakarta: Erlangga.

BPS DIY (2019). Pertumbuhan Ekonomi DIY Triwulan III-2019. Diakses di: https://yogyakarta.bps.go.id/pressrelease/2019/11/05/961/pertumbuhan-ekonomi-diytriwulan-iii-2019.html. 
Consuegra, D., Molina, A., \& Esteban, A. (2007). An Integrated Model of Price, Satisfaction and Loyalty: An Empirical Analysis in Service Sector. Journal of Product \& Brand Management, 16(7), 459-468.

Delima, A., Ashary, H. M., \& Usman, O. (2019). Influence of Service Quality, Product Quality, Price, Brand Image, and Promotion to Consumer Satisfaction Affecting on Consumer Loyalty (Online Shop). Journal Economics, 1(1), 1-15.

Dhasan, D., \& Aryupong, M. (2019). Effects of Product Quality, Service Quality and Price Fairness on Customer Engagement and Customer Loyalty. ABAC Journal, 39(2), 82102.

Griffin, J. (2005). (2005). Customer Loyalty: Menumbuhkan \& Mempertahankan Kesetiaan Pelanggan. Jakarta: Erlangga.

Hair, J.F., Black, W.C., Babin, B.J., Anderson, R. D. (2010). Multivariate Data Analysis. 7th Edition. New Jersey: Prentice-Hall, Inc.

Hanaysha, J. (2016). Testing the Effects of Food Quality, Price Fairness, and Physical Environment on Customer Satisfaction in Fast Food Restaurant Industry. Journal of Asian Business Strategy, 6(2), 31-40.

Ishaq, M. I., Bhutta, M. H., Hamayun, A. A., Danish, R. Q., \& Hussain, N. M. (2014). Role of Corporate Image, Product Quality and Customer Value in Customer Loyalty: Intervening Effect of Customer Satisfaction. Journal of Basic and Applied Scientific Research, 4(4), 89-97.

Jahanshahi, A. A., Gashti, M. A. H., Mirdamadi, S. A., Nawaser, K., \& Khaksar, S. M. S. (2011). Study the Effects of Customer Service and Product Quality on Customer Satisfaction and Loyalty. International Journal of Humanities and Social Science, 1(7), 253-260.

Joudeh, J. M., \& Dandis, A. (2018). Service Quality, Customer Satisfaction and Loyalty in an Internet Service Providers. International Journal of Business and Management, 13(8), 108-120.

Karyose, H., Astuti, W., \& Ferdiansjah, A. (2017). Customer Loyalty: The Effect of Service Quality, Corporate Image, Customer Relationship Marketing and Customer Satisfaction as Intervening Variable-An Empirical Analysis of Bank Customers in Malang City. Marketing and Branding Research, 4, 336-347.

Khoironi, T. A., Syah, H., \& Dongoran, P. (2018). Product Quality, Brand Image and Pricing to Improve Satisfaction Impact on Customer Loyalty. International Review of Management and Marketing, 8(3), 51-58.

Kotler, P., \& Keller, K. L. (2016). Marketing Management. 16th Edition. Ohio: Pearson.

Lovelock, C. H., \& Wright, L. K. (2007). Manajemen Pemasaran Jasa. Jakarta: Penerbit Indeks.

Lupiyoadi, R., \& Hamdani, A. (2008). Manajemen Pemasaran Jasa. Edisi ke-2. Jakarta: Salemba Empat.

Marina, S., Kartini, D., Sari, D., \& Padmasasmita, S. (2016). Customer Loyalty as the Implications of Price Fairness Determined by Relationship Marketing and Service Quality of Airline Services. Southeast Asia Journal of Contemporary Business, Economics and Law, 11(2), 43-51. 
Meesala, A., \& Paul, J. (2018). Service Quality, Consumer Satisfaction and Loyalty in Hospitals: Thinking for the Future. Journal of Retailing and Consumer Services, 40, 261-269.

Mohsan, F., Nawaz, M. M., Khan, M. S., Shaukat, Z., \& Aslam, N. (2011). Impact of Customer Satisfaction on Customer Loyalty and Intentions to Switch: Evidence from Banking Sector of Pakistan. International Journal of Business and Social Science, 2(16), 263-270.

Mullins, J., Walker, O., Larreche, J. C., \& Boyd, H. W. (2005). Marketing Management: A Strategic Decision Making Approach. 6th Edition. New York: McGraw-Hill, Inc.

Oktavia, E. (2019). Kejar Target, Deretan Bisnis yang Buka Cabang di Lampung Akhir 2019. Lampung Geh. Diakses di: https://kumparan.com/lampunggeh/kejar-targetderetan-bisnis-yang-buka-cabang-di-lampung-akhir-2019-1sBF3SXEi5t/full.

Olivia, G. (2020). Bank Dunia: Ada 115 juta Penduduk Indonesia Berpotensi jadi Kelas Menengah. Diakses di: https://nasional.kontan.co.id/news/bank-dunia-ada-115-jutapenduduk-indonesia-berpotensi-jadi-kelas-menengah.

Rimawan, E., Mustofa, A., \& Mulyanto, A. D. (2017). The Influence of Product Quality, Service Quality and Trust on Customer Satisfaction and Its Impact on Customer Loyalty (Case Study PT ABC, Tbk.). International Journal of Scientific \& Engineering Research, 8(7), 2330-2336.

Setiawan, H., \& Sayuti, A. J. (2017). Effects of Service Quality, Customer Trust and Corporate Image on Customer Satisfaction and Loyalty: An Assessment of Travel Agencies Customer in South-Sumatra Indonesia. IOSR Journal of Business and Management, 19(5), 31-40.

Stan, V. (2015). Does Consumer Gender Influence the Relationship between Consumer Loyalty and Its Antecedents? Journal of Applied Business Research, 31(4), 1593 1604. https://doi.org/10.19030/jabr.v31i4.9339.

Subaebasni, S., Risnawaty, H., \& Wicaksono, A. A. (2019). Effect of Brand Image, the Quality and Price on Customer Satisfaction and Implications for Customer Loyalty PT Strait Liner Express in Jakarta. International Review of Management and Marketing, 9(1), 90-97.

Tjiptono, F. (2008). Strategi Pemasaran. Edisi ke-3. Yogyakarta: Andi Offset.

Wu, C. C., Liao, S. H., Chen, Y. J., \& Hsu, W. L. (2011). Service Quality, Brand Image, and Price Fairness Impact on the Customer Satisfaction and Loyalty. IEEE International Conference on Industrial Engineering and Engineering Management, 1160-1164.

Yaqub, R. M. S., Halim, F., \& Shehzad, A. (2019). Effect of Service Quality, Price Fairness, Justice with Service Recovery, and Relational Bonds on Customer Loyalty: Mediating Role of Customer Satisfaction. Pakistan Journal of Commerce and Social Sciences (PJCSS), 13(1), 62-94. 